\title{
ASPECTS ON THE WATER SOURCES QUALITY IN COUNTRYSIDE
}

\author{
Ph.D.Eng.Lecturer Anca Serban, \\ Ph.D.Eng.Lecturer Mariana Carmen Burtea \\ "Dunarea de Jos" University of Galati
}

\begin{abstract}
Both surface and underground water sources represent national treasures that need to be managed according to the sustainable use principle in order to maintain their quality properties. If the surface water pollution is obvious from sources such as atmospheric emissions, waste waters, chemical residues, the underground waters are not free from pollution, even some pollutants diffuse to depths of tens or hundreds meters. Unfortunately the countryside as well as the urban area, is affected by pollution as there are areas where the wells water is the only water source available for the population.
\end{abstract}

KEYWORDS: water, phreatic, pollution, countryside

\section{Introduction}

The anthropic pressure on the water sources is the human activity exerted on a watercourse and can change its ecological and chemical state in time and space. Considering the human activities carried out, there are the following types of pollution [1]:

-chemical pollution such as sewerage systems and purification plants, industrial and agricultural economic agents evacuating treated / unpurified / insufficiently treated wastewater into natural receptors, human agglomerations that do not have wastewater collection systems or appropriate sludge collection and disposal systems in sewage treatment plants, agrotechnical farms that do not have adequate storage / use systems for manure, potentially vulnerable areas to nitrate pollution from agricultural sources.

- hydromorphological pressures represented by infrastructure constructions in the field of water management such as amendments of natural debits, defence against the destructive effects of water.

The surface water sources pollution endanger the underground water quality by infiltration of polluting substances into the aqui fer deposits where water flows slowl $y$ and the natural process of water purification takes longer and is harder to achieve than surface water. Thus pollution that occurred decades ago whether it derived from agriculture, industry or other human activities can still threaten the quality of water today and tomorrow for an unknown period of time.

\section{The groundwater protection}

Groundwater makes up the largest reservoir of freshwater in the world, accounting for over $97 \%$ of all freshwater available on earth. In EU $75 \%$ of drinking water residents depend on groundwater [2].

In different phases of the hydrological circuit in nature, water undergoes various transformations under the influence of environment and human activities. Thus the groundwater sources of pollution mainly refer to:

-the discharge of substances into the underground by percolation from septic tanks, leakage from injection wells from discharging wastewater or wells loaded with different substances, flowing from irrigation systems;

- accidental losses from facilities performed for the storage, storage and/or treatment of pollutants.

The EU Water Framework Directive 2000/60/EC stipulates for 2015 the achi evement of good quantitative, ecological and chemical status of underground water and also sets out general provisions for its protection and conservation. The Groundwater Directive (GWD) 2006/118/EC on the protection of 
groundwater against pollution and deterioration refers to criteria for assessing groundwater chemical status and measures to prevent or limit inputs of pollutants into groundwater. Thus the assessment of groundwater chemical status is achieved by groundwater quality standards implementation, measures to prevent or limit inputs of pollutants into groundwater, threshold values for groundwater pollutants and indicators of pollution [3].

In Annex II of Directive 2006/118/EC is presented the Minimum list of pollutants and their indicators for which Member States have to consider establishing threshold values. It was expected that most Member States would establish threshold values for the pollutants of concern. Thus the substances or ions or indicators which may occur both naturally and/or as a result of human activities are: Arsenic, Cadmium, Lead, Mercury, Ammonium, Chloride, Sulphate; the man-made synthetic substances:

Trichloroethylene, Tetrachloroethylene; the parameters indicative of saline or other intrusions: Conductivity.

In total, threshold values have been established for 158 different pollutants/indicators, of the following groups [4]:

-12 Core substances (10 substances of GWD

Annex II part B together with ammonium as nitrogen and with the sum of Trichloroethylene and Tetrachloroethylene);

-39 Pesticides;

-8 Nutrients (e.g. nitrate, nitrite, phosphorus etc.);

-21 Metals;

-62 Synthetic substances;

-10 Other substances (e.g. Boron, Calcium, Bromate, Cyanide etc.);

-6 Indicators (e.g. acid capacity, hardness, pH etc.).

The number of threshold values established by each Member State varies between zero (Portugal) and 62 (United Kingdom) (figure 1) [4].

For naturally occurring substances, the main elements causing differences in the threshold values are the individual background levels and the different receptors (ecosystems and uses) and risks considered individually.

For synthetic substances, the background levels are not relevant and the elements causing the differences are various receptors (ecosystems and uses) and risks.

The threshold values establishment required the consideration of different receptors of groundwater body as well as the risks and functions, the characteristics and behaviour of the pollutants and the hydro-geological characteristics represented by the background levels.

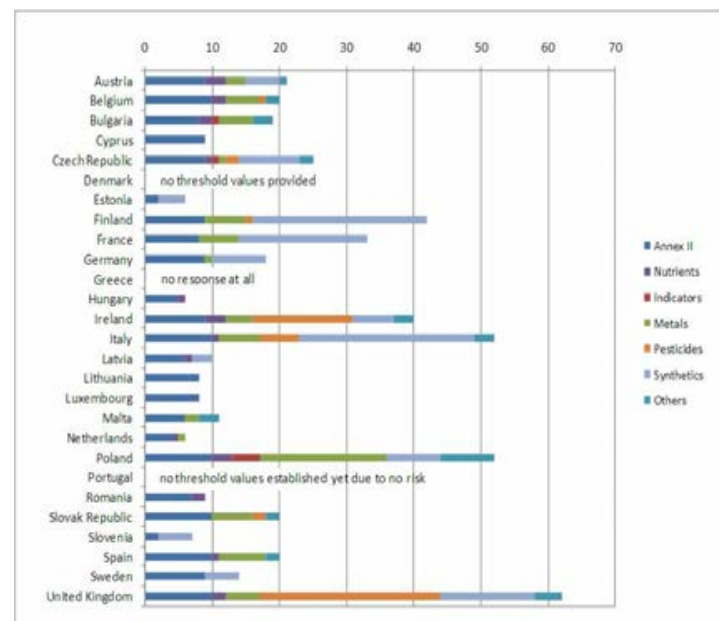

Figure 1. The Number of pollutants/indicators for which threshold values have been established by each Member State

The Directive 91/676/EEC concerning the protection of waters against pollution caused by nitrates from agricultural sources must be considered together with the Groundwater Directive for the main cause of pollution from diffuse sources is affecting the Community's waters by increasing nitrates content. In this regard, the EU countries must designate as vulnerable zones all those draining into waters which are or could be affected by high nitrate levels and eutrophication, establish mandatory action programmes for these areas, monitor the effectiveness of the action programmes, test the nitrate concentration in fresh ground and surface water, deliver monitoring programme for these areas, set a code of good agricultural practice for farmers.

\section{The geomorphology and hydrology of the studied area}

The sampling area is located in South-East of Romania and occupies part of the Lower Siret Meadow, part of the Baragan Plain and in the East it includes the Big Island of Braila. The climate is temperate continental characterized by high temperature variations between summer and winter. The average annual temperature is + $11^{\circ} \mathrm{C}$. The plain area has a generally uniform relief with wide valleys and closed depressions. The hydrographic system is made up of flowing streams, tablelands and lake depressions [5]. The most important hydrographical artery of the area is the Danube with its two main streams: towards Dobrogea is the Macin Branch (the Old Danube) and the Cremenea Branch towards the Braila Plain. The Siret River also defines the northern part of the area, the Buzau river 
crosses the north-west part and the Calmatui River passes through the southern central area. Hydro-geologically, the area has two layers of water:

- the phreatic aquifer, settled in the permeable alluvial deposits at the base of loess;

- the medium-depth aquifer layer, identified in the inferior sands and gravel beds.

The phreatic aquifer layers are positioned according to depth in this manner:

- layers of small depth up to 40 meters supplied or not by nearby surface water;

- layers of high depth over 40 meters without being under the direct influence of surface waters.

These deposits can provide significant flows and are located at depths greater than 40-60 meters.

The underground water comes from the direct infiltration of atmospheric precipitation, the infiltration of surface water through the permeable banks of rivers and lakes, the condensation of water vapour in the underground rocks pores.

The phreatic aquifer of small depth is captured through wells inside households.

The evaluation of phreatic aquifer quality and volume is achieved by monitoring the chemical and physical parameters of groundwater bodies. Each area has a number of groundwater bodies which are demarcated and monitored according to its particularity. The physico-chemical parameters have threshold values and the groundwater bodies state is reflected in the following indicators values: nitrate, nitrite, ammonium, phosphates, chlorides, sulphate, dissolved oxygen, conductivity, $\mathrm{pH}$, alkalinity, hydrogen carbonates, cations as $\mathrm{Na}^{+}, \mathrm{K}^{+}, \mathrm{Ca}^{2+}$, $\mathrm{Mg}^{2+}$, dissolved iron and manganese, organic micro-pollutant and dangerous elements (arsenic, mercury, cadmium, lead).

The groundwater bodies considered at qualitative risk exceed the maximum permissible concentration in case of physicochemical parameters from agro-zootechnical and industrial activities.

\section{The qualitative evaluation of phreatic aquifer water}

The phreatic aquifer layers are small depth aquifers and are found in wells of rural households.

The groundwater samples were taken from wells in the countryside from an area on the bank of the Danube (table 1). Inside the village, the feeding phreatic layers of the wells are at a very low depth in the ground because due to the lack of rainfall and the increasing consumption of water the aquifer level has decreased.

Table 1. The groundwater samples from the South-West area near the left bank of the Danube River

\begin{tabular}{|c|c|c|}
\hline \multirow{2}{*}{$\begin{array}{l}\text { No. } \\
\text { Sample }\end{array}$} & \multicolumn{2}{|c|}{ Groundwater } \\
\cline { 2 - 3 } & Sampling Area & $\begin{array}{c}\text { Phreatic depth, } \\
\mathrm{m}\end{array}$ \\
\hline 1. & $\begin{array}{c}\text { Southern border of } \\
\text { the village }\end{array}$ & 10 \\
\hline 2. & $\begin{array}{c}\text { Northern border of } \\
\text { the village }\end{array}$ & 12 \\
\hline 3. & East & 3 \\
\hline 4. & West & 3 \\
\hline 5. & North & 3 \\
\hline 6. & South & 3 \\
\hline
\end{tabular}

The samples were taken in clean plastic containers according to the methodology of SR ISO 5667-6:1997.

The nitrate content was determined by colourimetric method with phenol disulphonic acid according to STAS 3048/1-77 [6]. The Nitrates are the final stage of oxidation of

Table 4. The quality indicators of water samples from the South-West area near the left bank of the Danube

\begin{tabular}{|c|c|c|c|c|c|c|c|}
\hline $\begin{array}{l}\text { Sample } \\
\text { no. }\end{array}$ & Sampling Area & $\begin{array}{c}\mathrm{pH} \\
\text { units }\end{array}$ & $\begin{array}{c}\text { Total } \\
\text { dissolved } \\
\text { solids, mg/l }\end{array}$ & $\begin{array}{l}\text { Alkalinity } \\
\mathrm{mg} \mathrm{HCO}_{3} / 1\end{array}$ & $\begin{array}{l}\mathrm{Cl}^{-}, \\
\mathrm{mg} / 1\end{array}$ & $\begin{array}{l}\mathrm{Ca}^{2+}, \\
\mathrm{mg} / 1\end{array}$ & $\begin{array}{l}\mathrm{N}^{-} \\
\mathrm{NO}_{3}^{-}, \\
\mathrm{mg} / 1\end{array}$ \\
\hline 1. & $\begin{array}{c}\text { Southern border } \\
\text { of the village }\end{array}$ & 8,15 & 1040 & 580 & 120 & 80 & 32,5 \\
\hline 2. & $\begin{array}{c}\text { Northern border } \\
\text { of the village }\end{array}$ & 7,59 & 2200 & 495 & 446 & 120 & 38,7 \\
\hline 3. & East & 8,09 & 918 & 466 & 78 & 80 & 16,2 \\
\hline 4. & West & 7,62 & 4700 & 512 & 1233 & 360 & 30 \\
\hline 5. & North & 7,99 & 2400 & 527 & 503 & 140 & 41,2 \\
\hline 6. & South & 7,84 & 4240 & 556 & 950 & 120 & 31,2 \\
\hline \multicolumn{2}{|r|}{ Permissible value } & $6,5-9,5$ & $100-800$ & 400 & 250 & 100 & 50 \\
\hline
\end{tabular}


organic nitrogen. Nitrogen is a nutrient for plants and along with phosphorus is used in intensive farming in agriculture. The nitrate values are quite high especially in northern area within the range 16,2-41,2 $\mathrm{mg} / 1 \mathrm{NO}_{3}{ }^{-}$ even if they do not exceed the admissible concentration.

The chlorides content was determined according to STAS 3049/88 [6]. Chlorine is found in water as chlorides most often of mineral nature, but also of organic nature giving the water a characteristic unpleasant taste salty or bitter. The chlorine content is below $250 \mathrm{mg} / \mathrm{C} \mathrm{Cl}^{-}$in two of the samples and above it in the other samples.

The total alkalinity towards methyl-orange was determined according to SR EN ISO 9963-1:2002. This is expressed in hydrocarbonate ions found in water compounds. The bicarbonate concentration varied in the range of $466-580 \mathrm{mg} / \mathrm{HCO}_{3}{ }^{-}$.

The calcium content was determined according to STAS 3662-62 [7]. The calcium ions concentration in water samples was under the limit value in two cases and above it in the other samples.

The total dissolved solids (TDS) content was determined by conductometric analysis with TDS meter according to STAS 9187/84 [7]. The analysis reflects the water salts content and shows a very high salt content of 918$4700 \mathrm{mg} / \mathrm{l}$.

The reaction of water samples was determined by potentiometric analysis with pH-meter according to SR ISO 10523/1997 [6]. The water samples reaction has low alcalinity at four of them and moderate alcalinity at two samples.

\section{Conclusions}

Although it is situated near the left bank of the Danube River, the studied area does not have the groundwater quality similar to that of the Danube water. Thus, the studied area has nitrate pollution potential from agricultural sources proved by the high nitrate content in water samples. This is explained by the precipitation percolation and nitrate ions drawing in soil and further in the phreatic layers followed by their concentration in this area. The nitrate content in groundwater is related to application of nitrogen-based fertilizers, domestic waste decomposition and incorrect gathering of wastewater from livestock. The protection of groundwater against accumulation of nitrates is also achieved by appropriate nutrient and irrigation water flow dosing so that the amount of water in precipitation and irrigation does not exceed the water capacity in the field. As indicative of saline character, the TDS content shows an increased mineralization of groundwater due to soil salts drawing into the phreatic layers and mineralization degree of the irrigation water. The influence that mineralized irrigation waters or contaminated waters have on groundwater is directly or indirectly reflected on the environment and human health. Thus, in order to prevent groundwater pollution, the irrigation water sources are selected only after testing their physical and chemical parameters. The hydro carbonate concentration in water exceeds the permissible value and is also reflected in the alkaline reaction of water samples. The groundwater samples have calcium salts such as bicarbonate and chlorides which give water a salty taste. The high content of TDS, nitrate, calcium and chlorides outlines the groundwater quality from which we conclude that the water from wells in the South-West area is not suitable for irrigation or for other uses in households. In order for the water to be used in households, wells must be periodically cleaned of water and mud with a mud or sand pump. Then after the water has reached again the usual level in well, it is possible to implement the well disinfection with chlorinated substances. The water from wells may be consumed only after performing physical, chemical and bacteriological analyses which confirm its potable character. Thus the phreatic aquifer of small depth in the countryside is primarily contaminated due to intensive farming practices, domestic waste decomposition and incorrect gathering of wastewater from livestock.

\section{References}

[1]. Annual environmental status report Brăila 2013

[2]. https://erncip-project.jrc.ec.europa.eu

[3]. Directive 2006/118/EC of the European Parliament and of the Council of 12 December 2006 on the protection of groundwater against pollution and deterioration).

[4].REPORT FROM THE COMMISSION in accordance with Article 3.7 of the Groundwater Directive $2006 / 118 /$ EC on the establishment of groundwater threshold values

[5].http://www.portal-braila.ro/dm/portal.nsf/ AllByUNID/00001542?OpenDocument

[6]. Legea $458 / 2002$ privind calitatea apei potabile republicata

[7]. STAS 1342 - 91 Apa potabila 